\title{
The Effort of Immigrant for Survival in a New Country, Study Case: Russia
}

\author{
Juniar Laraswanda Umagapi ${ }^{1}$ \\ ${ }^{1}$ Higher School of Economics, National Research University, Russia, \\ laraswanda17@gmail.com
}

\begin{abstract}
In this essay presents a critical understanding about immigrant way of living in a new country. Russia as a country with the big geographical aspect that also become a house for immigrant have their own special way to handle the immigrant. How the immigrant can socialize with the new environment and the issue facing for them as the newcomer in one society, how they get a proper job and how the culture difference influences their daily life will get analysed in this paper. This research is conducted in Russia and use a qualitative research method such as interviewing, data analysis, graph, table, book, journal, article, newspaper and news to answer the research question. This research will give the contribution how the issue of immigrant influences the life of native people, how they contribute to the society and how the Russian government policy dealt with the negative stereotype about immigrant in Russia then how we would help immigrants thrive, these are the question that this research will help to answer.
\end{abstract}

Keywords: Immigrant, Russia, culture difference, thrive, Russian government

\begin{abstract}
ABSTRAK
Dalam esai ini menyajikan pemahaman kritis tentang cara hidup imigran di negara baru. Rusia sebagai negara dengan aspek geografi yang terluas juga menjadi rumah bagi para imigran jadi mereka punya cara tersendiri untuk mengontrol arus imigrasi. Bagaimana imigran dapat bersosialisasi dengan lingkungan baru dan masalah yang dihadapi mereka sebagai pendatang baru di masyarakat, bagaimana mereka mendapatkan pekerjaan yang layak dan bagaimana perbedaan budaya mempengaruhi kehidupan sehari-hari mereka akan dianalisis dalam makalah ini. Penelitian ini di lakukan di Rusia karena penulis tinggal di Rusia dan menggunakan metodologi kualitatif dalam pengumpulan data seperti hasil wawancara, analisis data, grafik, table,buku,jurnal,artikel,koran dan berita untuk menjawab pertanyaan penelitiannya.Penelitian ini akan memberikan kontribusi bagaimana isu immigrant mempengaruhi kehidupan para masyarakat local,bagaimana imigran berkontribusi pada masyarakat dan bagimana pemerintah Rusia mengatasi image negative para imigran di Rusia dan kemudian Bagaimana kita akan membantu imigran untuk berkembang, inilah pertanyaan-pertanyaan yang akan di jawab dari hasil penelitian ini.
\end{abstract}

Kata kunci: Imigran, Rusia, perbedaan budaya, berkembang, pemerintah Rusia 


\section{Introduction}

Immigrant, a lot of perception about this term, and this term become so famous in the recent days. There are a lot of terms for the immigrant definition itself such as refugees, asylum seeker, regular migrants and forced migrant. But for this research we will focus on the refugees and forced migrant issue. Forced immigrant here they come because of the economical reason or because of the crisis I their own country. Many countries now have their own policy to handle the immigrant, people more concern with the fact that this country supports immigrant or not especially for those who come not because of their own choice but because something bad happens in their own country. Immigrant, they do not have a choice to move or not. This is what we called forced immigrant or even refugees. Later many of them will be an asylum seeker because they do not want to be back in their country because of the political issue and their background so they try to get protection by the government from another country because they know that their own country cannot protect them.

In Russia or even in many countries they do not have issue with regular migrant because they come with the document permission to come and mostly, they already have the regular jobs and do not have any issue to stay in other country for a long time. Refugees happen to have the internal conflict happens in their country, so they must move to survive and looking for the better life. It is not their choice to move so sometimes the immigrant does not have time to prepare everything to survive in a new country. Mostly the immigrant also does not move alone but bring their whole family, it is not an easy job to provide for yourself, and it is even more difficult to provide for a whole family more than 4-6 people. How Russia acts towards immigrants and the Russian perception regarding the immigrant and how the contribution of an immigrant in Russia towards the development of Russia itself.

When talking about immigrant, many types of immigrant live in another country, for example, temporary labour migrants, highly skilled and business migrants, irregular migrants, forced migration, family members, return migrants. Even legal and illegal immigrant is also very difficult to make the difference, sometimes they come only to get a job without a proper legal document and the other part of immigrants comes to Russia because of the domestic conflict happened in their country so they come in a rush without a proper legal document also.

The immigrant also divides because of their reason for coming to the new country. For example, because of the conflict in the borders or because of the domestic terrors that happens in the country. The crisis of immigrant reaches a peak when the Syrian immigrant crosses the border and make European government must work hard to facilitate the pressure population of an immigrant. For the immigrant that come to a new country only to get a proper life regarding their economic aspects, they have time to prepare their legal documents to stay in a new country and, they have time to prepare their language ability. But for the immigrant that comes because they do not have anywhere else to stay because of the terror happen in their own country, mostly they do not have time to prepare everything. They just come without knowing anything even the environment of the country then the language becomes the most barriers they are facing because they cannot speak or socialize with people. For former Soviet Union countries mostly, they do not have any difficulties because they speak the same 
language but for the other countries, they are facing difficulty.

Russia, the world's largest nation, borders European and Asian countries as well as the Pacific and Arctic oceans and the ninth most populous, with over 144 million people as of December 2017, excluding Crimea. About $77 \%$ of the population lives in the western, European part of the country. Russia's capital, Moscow is one of the largest cities in the world; other major cities include Saint Petersburg, Novosibirsk, Yekaterinburg and Nizhny Novgorod. ${ }^{1}$ A country that lead by the powerful man, President Vladimir Putin and famous with their foreign intervention in some of the conflicting parties. Russia relationship with the most powerful country like United States is interesting to discuss. The mind-set of people that never come to Russia is still that Russia is a dangerous country; people do not have freedom of speech because they are communism, but it is true or not is depend on people view. So, is it safe for immigrant to live there or not? Are the government supports the policy to immigrant to stay in Russia and how they survive will be analysed based on the findings.

Why this research focused in Russia, what makes Russia so interesting if we talk about immigrant issue. Firstly, Russia hosts the world's largest population of immigrants after the United States, according to a new UN study showing that the number of people living abroad across the globe has reached a record high. New figures released Wednesday by the UN Department of Economic and Social Affairs (UN-DESA) in New York indicated that 232 million people (3.2 per cent of the world's population) live abroad. Over

\footnotetext{
${ }^{1}$ Preliminary Assessment of the Period of Permanent Population as of January 1, 2018, and on average for 2017. Retrieved from: www.gks.ru.
}

11 million of them live in Russia, the study found. The US remains the most popular destination with a total 45.8 million migrants, while Germany (9.8 million) is ranked third after Russia, the UN study said. ${ }^{2}$

Secondly, Russian government policy towards refugees and forced immigrants. Russia is a migrant destination country with a steady flow of labour migrants and refugees. Depending on an individual migrant's situation or his or her country of origin, a migrant to Russia can be granted a refugee status or may receive temporary asylum. Refuge and temporary asylum policies are developed according to the nation's Constitution, a set of laws and federal regulations, and international obligations under the 1951 Convention and 1967 Protocol Relating to the Status of Refugees. The Federal Migration Service is the federal government agency with regional offices across the country that is in charge of implementing all migration-related policies, monitoring migration processes, and managing migrant assistance and resettlement programs. The Federal Migration Service of the Russian Federation (FMS), a government agency dealing with migration, reported that in 2014, 6,980 people from sixty-five countries applied for refugee status, and 267,764 people requested temporary asylum in the Russian Federation. ${ }^{3}$ It shows the government policy regarding the status of immigrant in Russia and how they dealt with

\footnotetext{
${ }^{2}$ Ria Novosti. SputnikNews. (2013, September 12). Russia Has World's $2^{\text {nd }}$ Largest Number of Immigrants-UN Study. Retrieved from: https://sputniknews.com/russia/201309121833847 82-Russia-Has-Second-Largest-Number-ofImmigrants--UN-Study/

${ }^{3}$ Federal Migration Service. (2014, December 31). Statistics on Asylum-Seekers on the Territory of the Russia Federation in 2014. Retrieved from: http://www.fms.gov.ru/document/18111 (in Russian)
} 
their situation after they move to Russia.

Mostly immigrant in Russia coming from the ex-Soviet Union country like Uzbekistan, Kazakhstan, Tajikistan, Kyrgyzstan, Turkmenistan, Azerbaijan because it is just closed with their own country and they use the same language, so the language barriers will not be a problem for them. They just come to work here and send back the money to their home. That is also the reason that people said if you see the workers in Russia but looks like the mix of Asia or China and have different features of the face with local Russia it must be from the Central Asia countries. They come for work because they believe in Russia they will have the better jobs compare with their own country.

Migration is a crucial factor in the erosion of traditional boundaries between languages, cultures, ethnic group, and nationstates. Even those who do not migrate are affected by movements of people in or out of their communities, and by the resulting changes. Migration is not a single act of crossing a border, but rather a lifelong process that affects all aspects of the lives of those involved. ${ }^{4}$

\section{The Methodology}

The intended research method would be twofold namely qualitative and case study method. The reason to use the qualitative approach is to make sure the main research problem would be ascertained. The main research problem here to explain how the immigrant lives in Russia especially refugees and forced immigrant, the contribution to the society and what barriers they are facing to

\footnotetext{
${ }^{4}$ UNESCO. Learning to Live Together. Retrieved from: http://www.unesco.org/new/en/social-andhuman-sciences/themes/internationalmigration/glossary/migrant/
}

live in a new country and how the policy of the government help them to survive in Russia. The image towards the refugee from the local people in one area, and how they can survive will get analysed in this paper.

The research problem will be also answered by collecting data, interviews, content of analysis documents; this will try to focus on understanding and explaining the meaning of a social phenomenon, happening inside the country, particularly in immigrant issue. The interview process will be the main process of these research methods because the author lives in Russia and interview mostly the people that get the impact from the immigrant and people that work in NGO that focused to handle immigrant such as MPC Social Services Moscow. MPC Social Services provides food assistance, medical care, education, and economic empowerment to poor and marginalized people in Moscow.

The methodology the author uses also to analyse the impact of the immigrants in Russia and in what capacity they can help the society. Finally, by analysing all collected data, summarize and prepare the crucial recommendation and contributing the main points to improve the government policy towards immigrant.

\section{Result and Discussion}

According to UN Population Division estimates, as of 2013, the Russian Federation was second after United States for the number of the immigrant. Many of the immigrants coming to Russia can earn much higher wages than they could in their home countries. While life for the average labour migrant in Russia is hard, to say the least, the conditions they leave behind are almost always much worse. If there are no jobs in your town in Uzbekistan or Kyrgyzstan (which are among the major sending countries according to both UN and Russian official statistics), trying 
your luck in Russia is likely your best option. ${ }^{5}$ The geographical reason, same culture, same language and work permit it is not so difficult for them to get it from Russia.

The figure below shows the migration flows to and from Russia until 2015, the immigration net level reaches a peak in 1994. It became possible due to the immigration growth, and the reduction of emigration. The domestic situation in Russia since the world war give unstable situation for people that need to stay in Russia or to move to another country. But since 1991 not many Russian people want to move to another country because it always shows the reduction of the percentage in emigration level, only until 2011 it shows a stable increase for the level.

\footnotetext{
${ }^{5}$ Mary Elizabeth Malinkin. The National Interest. (2014, August 10). Russia: The World's SecondLargest Immigration Haven. Retrieved from: http://nationalinterest.org/blog/the-buzz/russia-theworlds-second-largest-immigration-haven-11053
} 
Figure 1. Migration Flows to and from Russia, 1991-2015

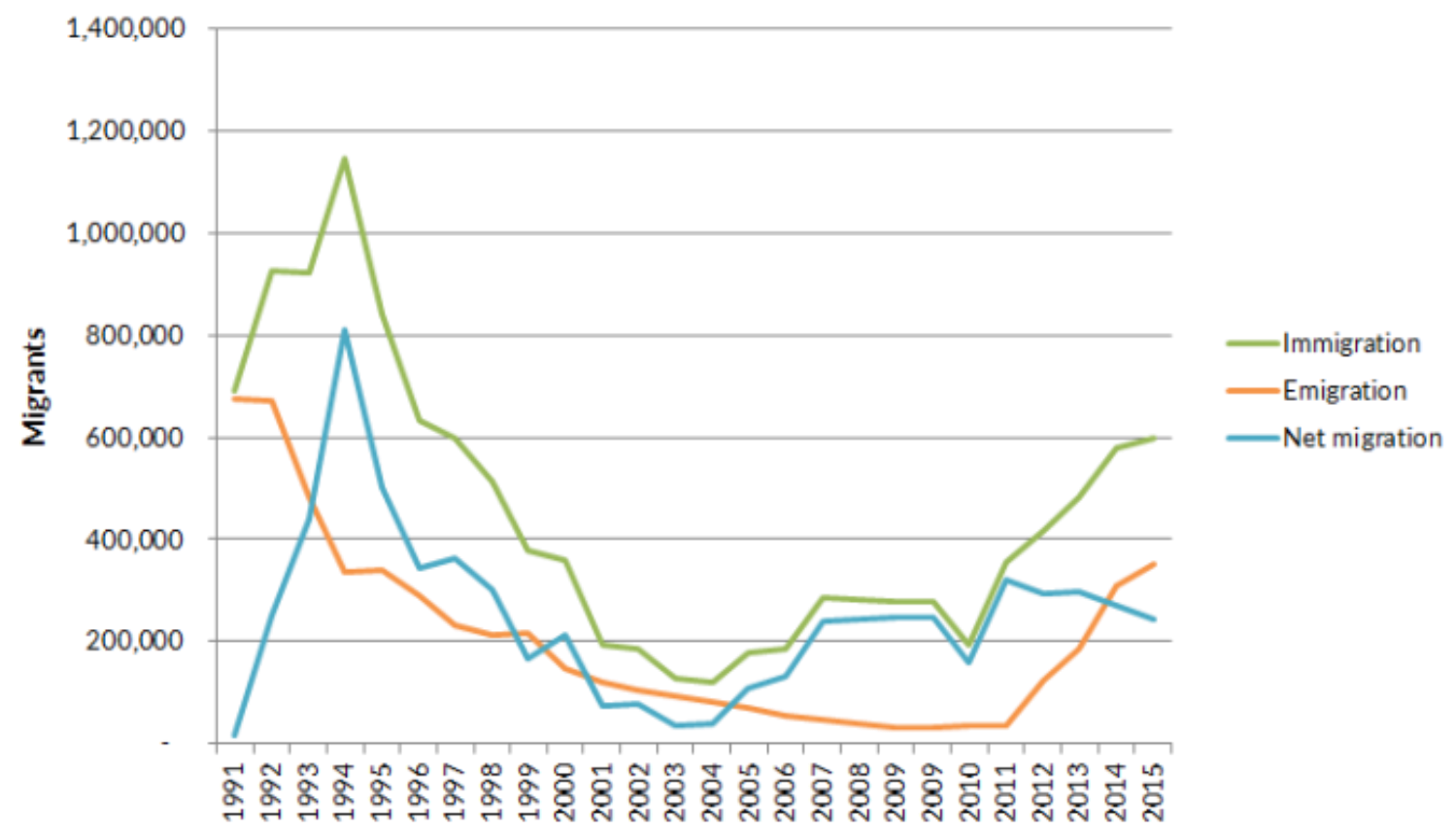

Note: Immigration figures refer to inflows of migrants who stay in Russia longer than one year. Source: Federal State Statistics Service (Rosstat), “International Migration," updated July 8, 2016, available online (in Russian).

A lot of immigrant in Russia, there is also one of the reasons the civil society want to help the immigrant to survive in Russia. The author joins one of the NGO in Moscow call MPC Social Service which helps the needs of the community, the poor and marginalized in Moscow that is living in Russia without a supportive social network to ensure safety, security, and health. Russian pensioners, single mothers, immigrants, and refugees receive care including access to food, medical consultation, clothing, and shelter. Currently, our community includes Russian, Afghans, and Africans (ranging from Nigeria to Madagascar) and speaks as many languages, including English, Russian, French and Spain.

As the main mission to help people especially the people without a social network like immigrants that is why beside food and health care. The volunteer also helps to teach them Russian language, so they can work here without face the difficulty in the communication process because this is the main requirements for people to work here. If we see the percentage mostly the immigrants come from African and mostly they can speak French so in this NGO many voluntary also can speak France, so they will be able to speak with the immigrants easily.

Many of the immigrants the author interviewed especially people from the ex Uni Soviet countries like Kazakhstan, Kyrgyzstan, Uzbekistan which is put a lot of high number of their people who live in Russia and African countries like Nigeria or Ghana, mostly they said because they need to have better jobs and income compare if they work in their own country so they can send the money back to their family in their home countries. That is also the reason why mostly immigrant in Russia come from those countries, they mostly work in the labour jobs or be a waiter 
and cleaning services here in Russia especially Moscow.

If we can see from the countries aspect like which countries dominated mostly the population in Russia, Central Asia countries still dominated the immigration level in Russia, many people from ex-Soviet
Union countries work in Russia because of the economic and geographical reason. Every year immigrant from the ex-Soviet Union countries comes to work and work in the labour sector in Russia. 
Table 1. Net Migration in Russia by Period, 1991-2015

\begin{tabular}{|l|r|r|r|r|}
\hline Country or Region & $1991-2000$ & $2001-10$ & \multicolumn{1}{|c|}{$2011-15$} & $\begin{array}{c}\text { Overall } \\
(1991-2015)\end{array}$ \\
\hline $\begin{array}{l}\text { Former Soviet } \\
\text { Union Total }\end{array}$ & $4,280,000$ & $1,816,800$ & $1,366,100$ & $7,462,800$ \\
\hline Kazakhstan & $1,497,400$ & 347,400 & 182,700 & $2,027,400$ \\
\hline Uzbekistan & 605,000 & 349,000 & 202,000 & $1,155,900$ \\
\hline Ukraine & 341,600 & 261,500 & 341,800 & 944,900 \\
\hline Tajikistan & 314,700 & 135,700 & 129,800 & 580,200 \\
\hline Kyrgyzstan & 272,900 & 179,400 & 109,700 & 562,000 \\
\hline Armenia & 200,000 & 188,700 & 140,400 & 529,200 \\
\hline Azerbaijan & 298,900 & 120,500 & 79,400 & 498,800 \\
\hline Georgia & 358,700 & 70,900 & 27,400 & 457,100 \\
\hline Moldova & 78,500 & 106,100 & 93,000 & 277,600 \\
\hline Turkmenistan & 116,100 & 43,200 & 17,000 & 176,300 \\
\hline Latvia & 109,700 & 6,800 & 4,300 & 120,700 \\
\hline Estonia & 66,400 & 2,400 & 3,600 & 72,400 \\
\hline Lithuania & 46,600 & 2,900 & 2,000 & 51,500 \\
\hline Belarus & $-26,500$ & 2,200 & 33,200 & 8,900 \\
\hline United States & $-100,200$ & $-23,500$ & $-2,900$ & $-126,600$ \\
\hline Israel & $-176,400$ & $-6,500$ & 300 & $-182,600$ \\
\hline Germany & $-857,400$ & $-178,300$ & -300 & $-736,000$ \\
\hline Non-Former Soviet \\
Union Total & $-217,300$ & 59,900 & $-1,028,700$ \\
\hline
\end{tabular}

Note: Green represents positive net migration, while red represents negative net migration. Estimates of overall net migration vary based on methodology, with another estimate based on the demographic balance method placing the figure at 9 million from 1991 to 2015.

Source: For data since 1997, see Rosstat, "International Migration," updated July 8, 2016, available online (in Russian); data prior to 1997 from unpublished reports obtained by the authors from Rosstat and the former Federal Migration Service of Russia (now the Directorate General on Migration Issues in the Ministry of Interior) on Olga Chudinovskikh and Mikhail Denisenko (2017) "Russia: A migration System with Soviet Roots" on 18 May 2017 available at https://www.migrationpolicy.org/article/russia-migration-system-sovietroots

Many of the migrants tend to come and go and it is just the daily situation in a country, in general, they are not likely to be the doctors, programmers and other whitecollar workers who are welcomed to the U.S. and developed Europe. Still, their efforts help keeps their home countries afloat. Ukraine has 4.4 million migrant workers in the rest of Europe, most of them in Russia, according to IFAD. It receives $\$ 7.6$ billion a year in remittances from them. Belarus, Moldova, Tajikistan and Uzbekistan are all dependent 
on the money their citizens send home from Russia. $^{6}$

Vladimir Kozlov (Associated Professor department of demography in National Research University Higher School of Economics) state that "even immigrant find difficulty to live in Russia because not many immigrants come here with good skill and they are still facing the difficulties with the local people to find the jobs. That why not all people got an excellent job and just be a waiter, cleaning services or any other lowincome jobs. How do immigrants help Russia and vice versa? Selective immigration policies are obviously an issue, but there are efforts to help migrants who have not come in through these selective policies. Russian language programs help immigrants overcome language barriers and find jobs in Russia. Russia also increasingly has many charitable organizations that help immigrants. Of course, since we do not have rapid economic growth and we are not as big a destination for immigrants as other countries like Germany or the UK, the immigrant issue is not too big. Nevertheless, we're working to make Russia a safe place for immigrants". 7 Migrants want the same opportunities as local people, but when they put their children in local schools, discrimination becomes a big issue. If migrant's children could feel like they are Russians and get properly socialized at Russian schools, then the immigrant discrimination issue could get solved and the

\footnotetext{
${ }^{6}$ Leonid Bershidsky. Bloomberg. (2015, June 16). Why Russia still attracts Immigrants. Retrieved from: https://www.bloomberg.com/view/articles/201506-15/why-russia-still-attracts-immigrants

${ }^{7}$ Interviewed method for collecting data Vladimir Kozlov as Associated Professor department of demography in National Research University Higher School of Economics.
}

treatment of immigrants could be better. Part of the adjustment problem also is how life changes after immigration because of cultural shock.

The stereotype that Russia is a dangerous country also overshadows how welcoming Russia can be to immigrants. But, this isn't a big issue if immigrants want to get a job here. There is some issue regarding the discrimination towards immigrants in Russia, how they must survive in the new place, culture, and the situation will always be the hot issues of immigrants. Moscow Protestant Chaplaincy's (MPC) Task Force Against Racism has documented reports of attacks and harassment among the African community during the first half of 2016. Through interviews with 42 people of colour, the Task Force documented 20 incidents of harassment, 12 incidents of harassment by police, and 7 racially motivated attacks. ${ }^{8}$

Despite about what happened regarding the racism issue in Russia still do not make immigrant to leave the country because Russia still a safe place to live in based on the immigrant perspective compare with other country. As their military and security are among the best in the world, the paradigm of people that is Russian is dangerous country and their people are not nice only an issue and it is depend on yourself, they are not good in the first impression but if you know them very well actually, they are very welcome for the foreigner or immigrant. The problem only about illegal immigrants, not all immigrant come to Russia is legal they are come without any proper documents and without any skill to survive so the policy in Russia tries to take them back home.

On the recent years, Russian police officers launched a no-nonsense crackdown

\footnotetext{
${ }^{8}$ MPC Social Services data report about racism in Russia.
} 
on suspected illegals working on stalls in a market, more than 1,000 suspected illegals, mostly from Central Asia and former Soviet states such as Belarus and Kazakhstan become a target of the polices. Relative to 2015, respondents reported less racially motivated harassment and violence in the first half of 2016 than in previous years. For example, in 2015, 67\% reported harassment and $54 \%$ physical violence, whereas $48 \%$ reported harassment and $17 \%$ reported violence in this survey period in 2016. Institutional harassment often takes the form of targeting by the police. In the first half of 2016, 29\% of re spenders reported being stopped by the police, $50 \%$ of whom paid a bribe to leave. ${ }^{9}$ This looks like the policy specially targeting immigrant. After this issue becomes hot in the national television, the image of immigrant become worse and native people have the mind-set that the criminal action happened near the immigrant the suspect will obviously is the immigrant, but actually if we see in the broader perspective actually the immigrant is the victim here.

Many report the same story: the police stop you, ask for your documents and if you do not have documents, they will take your money. Refugees waiting for official status might live in such a state for years. Narrative reports of these and other encounters with racism in Moscow shed further light on the difficulties of life in Moscow for people of colour. Stereotypes regarding people of colour are still bad, because for their perception people from another country bring a lot of negative impact

\footnotetext{
${ }^{9}$ Tom Kelly for the Daily Mail. (2013, July 31). Spread-eagled against the wall and marched off single-file: How Russia deals with illegal immigrants. Retrieved from: http://www.dailymail.co.uk/news/article2381878/How-Russia-deals-illegalimmigrants.html\#ixzz4MMCs55N9
}

in the country. They are afraid of the criminal things done by the immigrant; that people without a proper document will get a harsh punishment by the police officer.

As a human being, we believe that we need to help each other and try to understand each other problem, even you do not want to help just do not do something that will cause a problem to the immigrants. The racism issue will be the immigrant real problem that is why we are in the MPC social services, one of the NGO that focused in provides food assistance, medical care, education, and economic empowerment to poor and marginalized people in Moscow especially refugees. MPC social services try hard to monitoring and educate people especially young people in Russia that we need an open heart to welcome an immigrant and they have the rights also to live here if they are not illegal and get permission from the government.

Imanni Burg as Executive Director at MPC Social Services said that very clear that "Immigrant contributed a lot of the society for example in the jobs because Russia needs a lot of people in the construction sector done by immigrant especially Tajikistan. An immigrant in Russia mostly help for the jobs in the construction or become a labour and its really help the economic sector in Russia. We must care about immigrant also because they also contributed to the economic sector of Russia, that is why many politician, government, elites now give their support to the program that help immigrant, it must be continuing program, not only give jobs and it is stop but also give the training, teach them and make sure that the immigrant children do not face any racism in their school because it will influence their psychology". That is why we need to help immigrant, so the impact will be vice versa, and they also will not encounter any problem in the future. Language barriers as the most important aspect of the 
communication with the local people will help them also in doing their work and for make Russian people easier to understand the immigrant. ${ }^{10}$

It is not so many immigrants cause a problem in society, it is just happening that they have a lack of the support from people coming to the society if they do not have chance to learn the language and have some misunderstanding because of the language it will give them not a lot of chance to give their contribution in the society. The understanding of the language in their native country will help them get out of their entire problem and the immigrant can face the conflict happen like racism if people will not mistreat them because of their title as the immigrant.

For a couple of decades, immigration has been contributing to the labour force in many countries in Europe and it is also happen in Russia. MPC social services, for example, help them for training and give a free lesson for a language course, give the medical treatment, food and help their kids to socialize in the school. That is kind of help will help them so much to improve their skill and survive here in Russia. Language is the most barrier that immigrant face because mostly when they decide to come here some because of the situation in their own country and they did not have much time to learn the language so when they are coming here it will be the most difficult part for them to get the job and understand the native language.

Another big issue most immigrants who live here is live far away with the native Russian which faces the standard life and they mostly live in the suburban to get the cheap price for a place and it is so difficult for them

${ }^{10}$ Interviewed Imanni Burg as executive director in MPC Social Services Center Moscow as one of the collected data methodologies to understand the situation in the city and to socialize with the condition. The government could do more to make sure that immigrant have the good chance to fighting like anybody else. Young people can set the example for other people to follow that they are welcoming the immigrants, so they will not treat them that they are different.

Russia government never said that they will help immigrant and have special policy towards them because it is very hard to control the entire immigrant who come to Russia especially immigrant from the conflicting countries. For example, Syrian refugees, Russia blame Western powers for Europe's migration crisis. In 2015, Russia only granted asylum to only two Syrian. ${ }^{11}$

\section{Conclusion}

Russian public and the elites were quite surprise when in the news the media stated that Russia has become an immigration country. The government policy shows still inconsistency towards the policy, people still wonder which position Russian holds, it is really banning the immigrant or give permission for them to live in Russia. If Russia want to be a country that give permission to all the immigrant to have comfortable life to live in Russia, they need to change their policy for the immigrant procedure to move to become more easy and try to stop the police to always asking question for the immigrants in the street, it makes them uncomfortable to live in Russia.

Abstracting from lower participation rates, immigration increases the labour force of the receiving country. This growth of

\footnotetext{
11 Howard Amos. The Telegraph. (2015, September 10). Russia refuses to help Syrian refugees. Retrieved from:

https://www.telegraph.co.uk/news/worldnews/euro pe/russia/11856922/Russia-refuses-to-help-Syrianrefugees.html
} 
labour supply affects average wages in the economy if other factors of production like capital are fixed due to changes in relative scarcities. The nature of the migration will impact education levels, ages, and tenures of immigrants, and consequently their probable assimilation. When migrants have the power to choose, the nature of the migration will also impact the host country selected. ${ }^{12}$

Immigrant and the native people must understand this situation so they can live together without any violence, the discrimination towards immigrant must stop and not only the government have responsibility for this issue but all people must understand that if they do not want to help the immigrant just do not disturb them because they have the rights to live in any country if they bring all the legal documents and can work here without creating any critical issue.

The government have a legal law to force the immigrant to follow the regulation done by the country and its the difficulty for the immigrant also to survive for not have the legal documents to stay. Work permit becomes a huge barrier for the immigrant because for survive they need to work but sometimes the administration and requirements are so one side with the immigrant.

Countries like Canada, Finlandia, Switzerland are the most countries in Europe that welcome all immigrant to live there, if we can see in the positive side, the countries that have a less population and they do not have many people work as a labour, waiters or work in a factory. Immigrant help them with this issue, so the balance work can

${ }^{12}$ Sari Pekkala Keerr and William R Kerr. Economic Impacts of Immigration: A Survey. Harvard Business School: Working Paper. 2011 accommodate easily, the educated people in those countries will do not want to work as a labour, they want to work with the proper jobs and high position or maybe work in the government and work as a businessman.

The legal immigrant will face an easy work life compare than the illegal immigrant, work permit issue is still the important case in Russia. Even for people that come to Russia only for studying you also must require all the legal documents to bring, if your document has some technical mistake, they will deport you in your home country. Students from Asia countries experience this issue and must deal with the Russia police.

\section{References}

Amos, Howard. (2015). Russia refuses to help Syrian refugees", https://www.telegraph.co.uk/news/worldnews /europe/russia/11856922/Russia-refuses-tohelp-Syrian-refugees.html

Bershidsky, Leonid. (2015). Why Russia still Attracts Immigrants https://www.bloomberg.com/view/articles/20 15-06-15/why-russia-still-attracts-immigrants [Accessed June, 15 2015]

Chudinovskikh, Olga and Mikhail Denisenko (2017). Russia: A migration System with Soviet Roots. https://www.migrationpolicy.org/article/russia -migration-system-soviet-roots

Interviewed Imanni Burg as executive director in MPC Social Services Center Moscow as one of the collected data methodologies for this research using qualitative research 
Interviewed Vladimir Kozlov as Associated Professor department of demography in National Research University Higher School of Economics as one of the collected data methodologies for this research using qualitative research.

Kelly, Tom. (2013). Spread-eagled against the wall and marched off single-file: How Russia deals with illegal immigrants. http://www.dailymail.co.uk/news/article2381878/How-Russia-deals-illegalimmigrants.html\#ixzz4MMCs55N9 [Accessed June, 18 2017]

Kerr, Sari Pekkala and William $\mathrm{R}$ Kerr. (2011). Economic Impacts of Immigration: A Survey. Harvard Business School: Working Paper.

Malinkin, Mary Elizabeth. (2014). Russia: The World's Second-Largest Immigration Haven.

http://nationalinterest.org/blog/the-

buzz/russia-the-worlds-second-largest-

immigration-haven-11053

Novosti, Ria. (2013). Sputnik News "Russia Has World's $2^{\text {nd }}$ Largest Number of Immigrants-UN Study. https://sputniknews.com/russia/201309121833 84782-Russia-Has-Second-Largest-Numberof-Immigrants--UN-Study/

Preliminary Assessment of the Period of Permanent Population as of January 1, 2018 and on average for 2017. www.gks.ru. [Accessed February 23, 2018]

UNESCO. "Learning to Live Together" from http://www.unesco.org/new/en/social-andhuman-sciences/themes/internationalmigration/glossary/migrant/] [Accessed February, 10 2017] 